\title{
The Relationship Between Iranian Female Dentistry Students’ Metacognitive Awareness and Listening Performance in English for General Purposes (EGP)
}

\author{
Ismail Baniadam \\ Urmia University of Medical Sciences, Urmia, Iran \\ Nasim Meskini \\ Curriculum Development, Urmia, Iran \\ Afsaneh Afra \\ Ministry of Education, Urmia, Iran
}

\begin{abstract}
Metacognition is defined as the knowledge and ability to monitor and control cognitive conditions in the learning process. Listening is the most important skill of the four language skills in both learning and teaching, and plays an important role in our daily life. Although nowadays there is a deeper perception of listening, it needs more attention and research. Accordingly, the present study investigates the relationship between the Metacognitive awareness and listening performance of female Dentistry students in English for General Purposes (EGP) course in Urmia University of Medical Sciences (UMSU). To do so, 50 Iranian female dentistry students were participated in this study. They completed Metacognitive Awareness Listing Questionnaire (MALQ) and listening section of the final exam. First, the listening section of final exam was applied to the participants at classrooms by the teacher. Immediately after the administration of the examination, the MALQ were conducted. The analysis exposed a weak positive relationship between learners' Metacognitive awareness scores and listening performance. Although correlation was not high, still there is more correlation in problem solving, directed attention and planning evaluation than others.
\end{abstract}

Keywords: metacognitive, awareness, listening, female, EFL learners, EGP

\section{Introduction}

Learning languages is the process of dealing with four skills: listening, speaking, reading, and writing and in order learns to all skills perfectly we should use proper learning/teaching strategies. Among these four skills, listening is the skill of understanding spoken language and it is an important skill; perform as a reflection of other life activities (Lindsay \& Knight, 2006). In another view according to Bueno, Madrid, and McLaren (2006), listening is a psychological phenomenon, which happens in people minds. It acts as a social phenomenon in order to scaffold the elements. Listening is an essential skill which develops faster than

Ismail Baniadam, MA in TEFL, English Language Department, Urmia University of Medical Sciences, Urmia, Iran.

Nasim Meskini, Ph.D., Curriculum Development, Urmia, Iran.

Afsaneh Afra, MA in TEFL, English Language Department, Ministry of Education, Urmia, Iran. 
speaking and often affects the development of reading and writing abilities in learning a new language (Tafaroji Yeganeh, 2013). Listening is an important factor in bonding our ideas to one another and it is the recognition (being listen to) in the response from another person that makes our experience meaningful (Nichols, 2006).

Learning the second language is a complex process (Harputlu \& Ceylan, 2014). Some learners fulfill this task properly and some fail even they follow the same rules because learners have different ways of learning or individual differences affect the process of learning (Harputlu \& Ceylan, 2014). Learning strategies of the L2 learning spotlighted since the mid-1970s and defined as techniques for understanding, remembering, and using information that is intentionally used and consciously controlled by the learner (Rahimi \& Katal, 2012). This consciousness or awareness in the process of listening is related to the way listeners think about the listening process; plan, monitor, and evaluate the listening task; and how do listen (Rahimi \& Abedi, 2014). As listening presses mostly related to our mind and other similar factors, we should talk about the term Metacognitive knowledge. According to Flavell (1979), it refers to the knowledge of persons' related to personal characteristics, task characteristics, and available strategies in a learning situation which could act as a positive component and facilitate the learning or as a negative point and make inhibition and also this knowledge includes learners ability to connect the learning task required strategies (Vandergrift \& Goh, 2012). It is a bridge between areas, e.g., between decision making and memory, between learning and motivation, and between learning and cognitive development (Hoare, 2011). The present study intends to explore the relationship between the Metacognitive awareness and EFL learner's listening performance. Although there are some studies on Metacognition and listening, it seems that there is not enough attention to the self-regulation learning and listening. Most of the learners facing with problems feel demotivated in listening related to a wrong idea about listening.

\section{Research Question and Hypothesis}

The main purpose of the study is to investigate the relationships between the Metacognitive awareness and the listening proficiency of EFL students.

Is there any relationship between Metacognitive awareness and Iranian female EFL learners listening performance?

H0: there is no relationship between Metacognitive awareness and Iranian female EFL learners listening performance.

\section{Methodology}

\section{Participants}

The target population of the study was 50 female Dentistry students at upper intermediate and advanced proficiency language level at Urmia University of Medical Sciences (UMSU) that participated in this study in the spring and summer term of 2017. All of the participants had received English in school as a compulsory course in primary and secondary school before starting their voluntary attending in English language centers, and had upper intermediate and advanced language certificates with more than three years language experience from different languages institutes confirmed by Iranian Ministry of Education. Their age ranged from 18 to 22, selected randomly and voluntarily to complete the questionnaire. The participants were self-selected and research was focused only on female gender. 


\section{Research Design}

This study is based on correlation coefficient which measures the extent to which two variables tend to change together. The coefficient describes both the strength and the direction of the relationship and Pearson product moment correlation intended to evaluate the linear relationship between two continuous variables. A relationship is linear when a change in one variable is associated with a proportional change in the other variable. The data were collected using two separate instruments. The research was designed primarily to collect quantitative data to be analyzed. In order to collect the required data, two scales a listening proficiency test were administered in this study: Metacognitive Awareness Listening Questionnaire (MALQ) as one variable and the listening section of the final exam as the other variable. In addition, the scales included a demographic information section which contained questions concerning students' personal information such as age.

\section{The Metacognitive Awareness Listening Questionnaire (MALQ)}

The Metacognitive Awareness Listening Questionnaire developed by Vandergrift, Goh, Mareschal, and Tafaghodtari (2006) consists of 21 items. The items are rated on a six-point Likert scale rating from 1 (strongly disagree) to 6 (strongly agree). It evaluates L2 learners' "Metacognitive awareness concerning their perceived use of strategies while listening to oral texts” (Goh \& Hu, 2014, p. 260). It further assesses their perceptions with regard to the difficulty of listening skill and their self-efficacy in it. Five subscales are included in the questionnaire, namely problem-solving, planning and evaluation, mental translation, directed attention, and person knowledge. The first subscale is planning and evaluation that contains items about how learners plan ahead for listening and evaluate the outcome of their listening efforts (Items 1, 10, 14, 20, \& 21). The second subscale is problem-solving which consists of items on how learners monitor comprehension and solve difficulties as they arise (Items 5, 7, 9, 13, 17, \& 19). The third subscale of the questionnaire directed attention includes items on how learners maintain their attention and stay on task during listening (Items 2, 6, 12, \& 16). The fourth subscale, mental translation, comprises items indicating whether listeners use mental translation strategies as they listen (Items 4, 11, \& 18). Finally, person knowledge, the fifth subscale, contains items representing listeners' perceptions about the difficulty presented by L2 listening and their self-efficacy in L2 listening (Items 3, 8, \& 15). Items 3, 8, and 16 were stated negatively so that the participants would not indicate a favorable attitude towards marking only one side of the scale. Items 4, 11, and 18 represent the mental translation strategies, which the learners should avoid to become efficient listeners. Thus, these six items were reverse coded for overall interpretation of scores. The questionnaire was conducted in its original form. The reliability coefficient of MALQ calculated in this study was 0.879 . The coefficients for each subscale were appeared to be 0.756 for problem-solving, 0.559 for planning and evaluation, 0.767 for mental translation, 0.536 for directed attention, and 0.809 for person knowledge.

MALQ-items are randomly interwoven with others; some are negatively worded to avoid learners to mark only one side of the rating scale (mental translation); the internal reliability of the MALQ (Cronbach's alphas) for the items was respectable, ranging from 0.68 to 0.78 (Vandergrift et al., 2006). MALQ was useful to assess the extent to which language learners are aware of and can regulate the process of $\mathrm{L} 2$ listening comprehension; it is also intended to serve as a self-assessment instrument. Learners themselves can use it to appraise the awareness of the listening process as well as to reflect on their use of strategy when listening to texts in the L2. Taking the reverse coding into consideration, the maximum score of the Metacognitive awareness listening 
questionnaire is 126 points when every item is answered with "strongly agree"; in turn, the minimum score is 21 points when the respondents answer with "strongly disagree".

\section{Listening Section of the Final Exam}

The second instrument used in this study was the learners' English listening section of the final exam. These students' classroom experiences and knowledge was based on Top Notch and Summit Course Level by Pearson Longman Press. It was used to determine the participants' listening ability according to the own levels in English classes. It consisted of 10 multiple-choice (three options) questions. Students had listened to a scientist who was talking about whales and supposed to choose the correct answer. At first, they had 90 seconds to study the sentences. Then they listened to the podcast for about seven minutes. They listened to the program for the second time to correct or finish their work. Finally, they had 90 seconds to finalize their answers. Listening was about scientist who is talking about whales. There was a research team collecting information about the whale's tune and sounds and songs for long period of time, which compared it with new data and considered the difference between male and female voices and the way they changed it during the time and the voices conceived as a harmonic, like a piece of music. The test included general listening and multiple choice questions. Total of raw points was $\min =0, \max =20$ and each question had two points which converted into a scaled score of 0 to 20. The total number of the final examination was 100 and it contained five parts: reading, writing, speaking (as an interview), listening, and students class activities during the term. Each part assigned score was 20.

\section{Data Collection Procedures}

The teacher explicitly explains the Metacognitive listening methodology to the students in class instruction. Metacognitive processes are typically predicting, planning, monitoring, evaluating, and problem-solving (Goh, 2008). The investigation was conducted five intact classes at the same level. At first, the teacher informed the students about the purpose and procedure of the study. It was also emphasized that their participation would be anonymous and confidential. Then, the listening section of the exam was played to the participants. It took about 15 minutes to finish answering the questions. Immediately after the exam, the MALQ were administered. It took almost 10 minutes to complete them.

\section{Data Analysis}

Quantitative data obtained from the instruments were analyzed using Statistical Package for Social Sciences (SPSS), Microsoft excel. The questionnaire was analyzed by grouping items to the five categories (predicting, planning, monitoring, evaluating, and problem-solving). The subjects' responses to each item were counted. Then each item was considered within the group of items that address a specific category. Finally, the means of all the subjects' responses to each group of items were calculated. The mean supplies information on the average performance of all the subjects' Metacognitive strategies and informs the researcher about how subjects as a whole performed. For the research question, in order to find whether there is any significant correlation between listeners' Metacognitive awareness and their performance on EFL listening comprehension test, Pearson correlation coefficient was performed. All of the assumptions of Pearson correlation including continuous variables, related pairs (pair of values include listening and Metacognition), absence of outliers and linearity and homoscedasticity were met. 


\section{Result}

The research questions in the study try to explain whether there is a relationship between L2 listening proficiency and total score of MALQ. It further explores the association between L2 listening proficiency and the subscales of MALQ, namely mental translation, person knowledge, problem-solving, planning and evaluation, and directed attention. The minimum and maximum and means and standard deviations for the listening scores, the five MALQ subscales, and the overall MALQ score are presented in the Table 1.

Table 1

Descriptive Statistics for Listening Scores, Overall MALQ Scores

\begin{tabular}{llllll}
\hline & N & Minimum & Maximum & Mean & Std. Deviation \\
\hline Problem-solving & 50 & 13 & 26 & 19.49 & 2.887 \\
Directed attention & 50 & 11 & 20 & 15.63 & 2.262 \\
Person knowledge & 50 & 4 & 14 & 9.29 & 2.369 \\
Mental translation & 50 & 3 & 13 & 8.00 & 2.638 \\
Problem-solving & 50 & 18 & 32 & 25.73 & 2.919 \\
L2 listening proficiency & 50 & 12 & 20 & 18.10 & 1.723 \\
Metacognitive & 50 & 65 & 89 & 78.10 & 5.658 \\
\hline
\end{tabular}

On average, the participants scored 18.10 out of a maximum 20 in the final exam listening test, indicative of their approximately high listening proficiency. The standard deviation of 1.723 indicated that there was not a considerable variability in listening proficiency among the participants. The mean MALQ score was 78.10 on a six-point scale. This showed that the participants reported a high level of strategy use and confidence regarding listening. Of the five MALQ subscales, the participants scored considerably higher for problem solving $(\mathrm{M}=$ 25.73, $\mathrm{SD}=2.919)$, planning and evaluation $(\mathrm{M}=19.49$, $\mathrm{SD}=2.887)$, directed attention $(\mathrm{M}=15.63$, $\mathrm{SD}=$ 2.262), than for person knowledge $(M=9.29$, $S D=2.369)$ and mental translation $(M=8.00, S D=2.638)$. In order to examine the relationships between the listening scores, the five MALQ subscales, and the overall MALQ score, the Pearson Product-Moment correlation coefficient was calculated. The results are illustrated in the Table 2.

Table 2

Inter-correlations Among Listening Scores, MALQ Subscales Scores

\begin{tabular}{ll}
\hline & Correlation(r) with L2 listening proficiency \\
\hline Mental translation & 0.106 \\
Person knowledge & 0.154 \\
Problem-solving & 0.97 \\
Planning and evaluation & 0.22 \\
Directed attention & 0.112 \\
MALQ & $* * 0.2390$ \\
\hline
\end{tabular}

Note. ${ }^{* *}$ Correlation is significant at the 0.01 level (2-tailed).

\section{Quantitative Data Results}

Table 2 shows that the participants' overall MALQ scores $(M=78.10, \mathrm{SD}=5.658)$ were related to their scores in the final exam listening test $(\mathrm{M}=18.10, \mathrm{SD}=1.723)$. The relationship between L2 listening proficiency and Metacognitive awareness was statistically positive $(r=0.239, p<0.01)$. The higher the 
participants scored on the MALQ scale, the higher they scored on the listening test. The results further indicated that there was a higher correlation between L2 listening proficiency in the three subscales of MALQ: person knowledge $(r=0.154, p<0.01)$, direct attention $(r=0.112, p<0.01)$, and mental translation $(r=0.106$, $\mathrm{p}<0.01$ ). In addition, there was a small positive correlation between L2 listening proficiency and two of the MALQ subscales, namely planning and evaluation $(r=0.022, \mathrm{p}<0.01)$ and problem-solving $(\mathrm{r}=0.097, \mathrm{p}<$ $0.01)$.

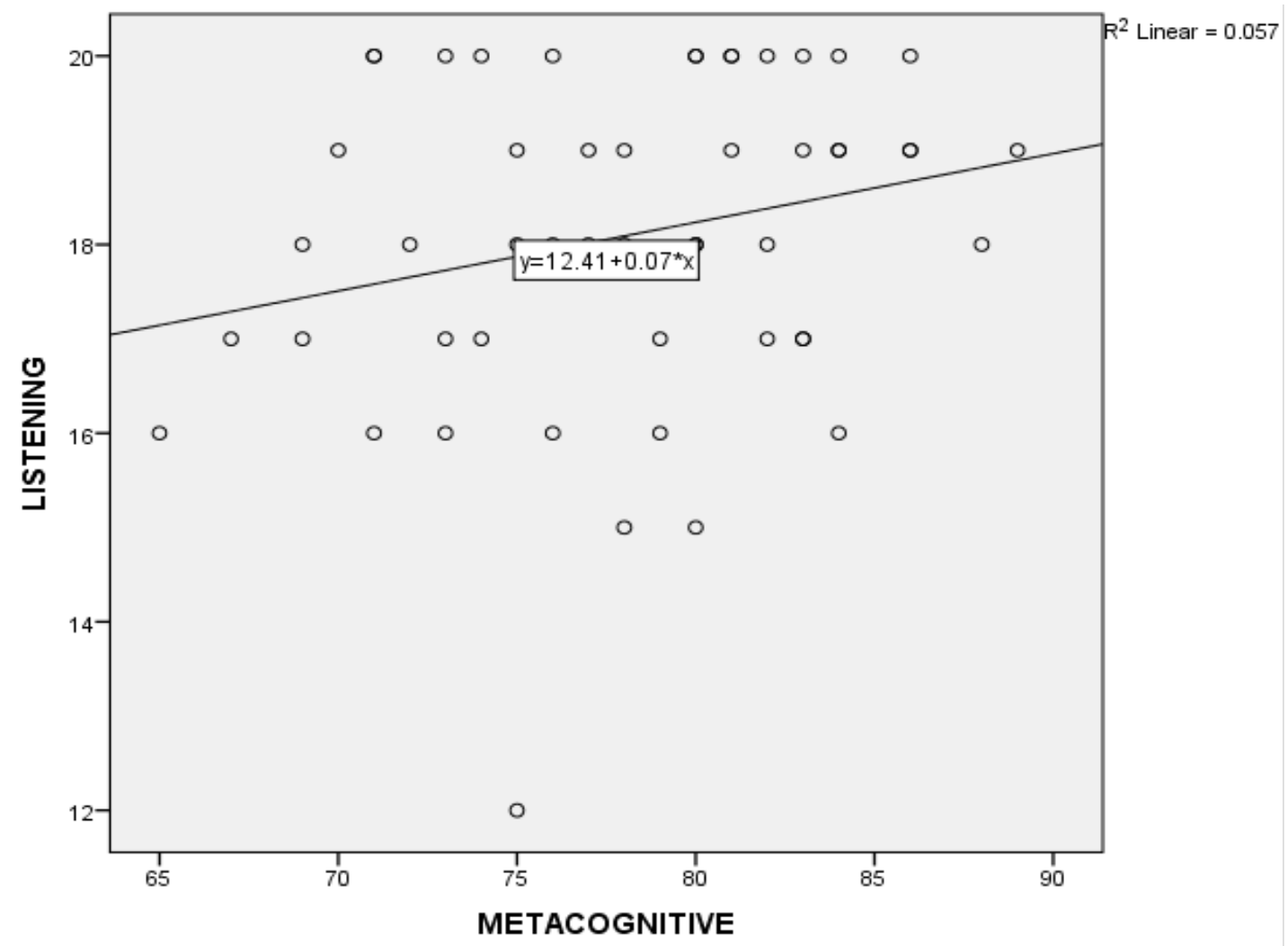

Figure 1. Scatter diagram for the correlation between MALQ and listening.

Using the Pearson Product-Moment Correlation to measure the strength of the relationship between the two variables of strategy and style, shows values of Pearson correlation coefficients (r) between -1 and +1 . The correlational matrix showed a positive association between the variables. Regression analysis model indicated that for each one-unit increase in Metacognition, listening will increase an estimated 7.3 units.

\section{Discussion}

The relationship between Metacognitive awareness listening and listening performance among female Dentistry students at UMSU has been investigated in this study. In this section, the findings of the present study are discussed and interpreted in light of the previous studies in past.

The results revealed a small positive relationship between Metacognitive awareness and listening proficiency. Moreover, L2 listening proficiency correlated with three types of Metacognitive strategies, person knowledge, directed attention, mental translation strategies, had more related than the others. Problem-solving strategies are the strategies used to infer the meaning of unknown words or phrases in listening passages 
through known words, prior knowledge, and contexts (Goh \& Hu, 2014). Planning and evaluation strategies enable students to prepare themselves for listening activities and analyze if their approach to the listening text is correct or not. Directed attention strategies can enable learners to ignore distracters and maintain attention during the listening performance (Vandergrift, 1997). Person knowledge is the knowledge a person has about himself or herself and others as cognitive processors to undertake a task (Flavell, 1979). Mental translations are those strategies that listeners must learn to avoid if they are to become skilled listeners (Vandergrift, 2003). Hence, the students who deploy these strategies are more likely to have a higher listening proficiency. Lower proficiency listeners are not likely to utilize those strategies due to the constraints they experience during listening such as the lack of vocabulary knowledge and the state of being unable to recognize the sounds of words known in print (Goh, 2000).

These results of the study appear to be consistent with previous studies which have pointed out a relationship between Metacognitive strategy use and L2 listening proficiency (Baleghizadeh \& Rahimi, 2011; Goh \& Hu, 2014; Rahimi \& Katal, 2012; Shirani Bidabadi \& Yamat, 2010; Tafaroji Yeganeh, 2013; Vandergrift et al., 2006). Since mental translation strategies are those which are used mainly by low proficiency listeners (Goh \& Hu, 2014; Vandergrift et al., 2006), these strategies prevent L2 listeners from keeping up with the incoming input; hence they cannot comprehend listening texts but in this research, participants used this strategy even more than problem solving and planning evaluation.

Finally, the results revealed a correlation between L2 listening proficiency and person knowledge. Person knowledge factor assesses how difficult learners perceive L2 listening, and what degree they have self-efficacy in it (Vandergrift \& Tafaghodtari, 2010). High anxiety and also low confidence affect the listening performance of L2 students. This result is consistent with the previous studies (Elkhafaifi, 2005; Goh \& Hu, 2014; Mills, Pajares, \& Herron, 2006; Ratebi \& Amirian, 2013). This study investigated the relationship between Metacognitive strategies and listening performance. The result of the study showed that students' level of Metacognitive listening strategy awareness is positive (small). This study is in line with findings of following studies like those (Akbari, 2003; Ratebi \& Amirian, 2013; Lachini, 1997; Pishgaman, 2009; Tajedin, 2001). Among the five main categories of Metacognitive strategies in MALQ, the directed attention and person knowledge were the most frequently use strategies and planning and evaluation was least. According to Vandergrift (2003), all EFL learners use strategies which help them to understand the listening part. The difference is that proficient listeners are more aware of how to use it properly.

The result of study based on Goh's ideas is beneficial in three ways:

1. It has effect in both process and product of the learning.

2. Metacognitive strategies make learners keep information easily.

3. They help learners to deal with challenging tasks better (Fahim \& Fakhri, 2014).

The Metacognitive instruction was beneficial in terms of improving listening proficiency and raising students' awareness of their L2 learning, the listening strategy use. The current study addressed the relationship between Metacognitive awareness strategy and EFL learners' listening comprehension performance. The p value was less than 0.01 and consequently, the null hypotheses which proposed are rejected. The results of present study confirmed that Metacognitive listening strategy awareness and listening comprehension of EFL learners are correlated (weak). The result of the study revealed that in general students' level of Metacognitive listening strategy awareness is satisfactory. This finding is in line with the findings of other studies that showed that Iranian students have (high) Metacognitive awareness in general (Akbari, 2003; Lachini, 1997; 
Pishghadam, 2009; Tajedin, 2001) and in listening strategies (Rahimi \& Katal, 2012; Bidabadiand \& Yamat, 2010; 2011).

However, it was also found that Iranian students' are not aware of their person knowledge strategies. Person knowledge refers to students' self-efficacy and ability to assess the perceived difficulty of the learning tasks. This study was in line with Liu and Hsueh's (2008) results that listening strategies had relationship with students' proficiency levels and Baleghizadeh and Rahimi's (2011) findings that there is a significant relationship between EFL learners' listening ability and their Metacognitive strategic knowledge since Metacognitive listening strategies enhance the EFL learners' listening performance.

This finding of the study can be explained by considering the fact that it rarely happens that Iranian students have a chance to evaluate their own strengths with the given task in the language classes because most of the time language courses in Iran focus on traditional techniques and teacher-centered methods (Rahimi \& Nabilou, 2009). Therefore, the concepts of self-assessment, self-awareness, and peer-assessment have not been truly developed among Iranian students, while the essence of most practices to improve Metacognitive skills is to engage students in collaborative activities such as peer assessments, collective reflection, and modeling Metacognitive processes (Choi, Land, \& Turgeon, 2005). As having students to plan, monitor, and reflect on their work could be applied to improve Metacognitive thinking and development, the need for reform in EFL curriculum in Iran is highlighted by this finding (Rahimi \& Katal, 2012). Based on Goh (2008), it was proven that Metacognitive instruction can improve learner's awareness of their listening ability to use proper strategies. This study obviously emphasized that using Metacognitive instructions in teaching listening increased language learners' Metacognitive knowledge which itself enhanced their comprehension and understanding of the purposes of the listening (Rahimi \& Katal, 2013).

According to the findings of the study, guidelines regarding the cultivation of Metacognitive awareness are made to the listeners and instructors. First, teachers ought to educate what Metacognition is and what is the function Metacognition performs in learning. This enables listeners to have a complete understanding of listening tasks and listening strategies and consider personal factors that can facilitate or hinder listening. Second, instructors should perform activities where listeners have opportunities to practice Metacognitive strategies, like discussing strategy use in the listening classroom, how to improve listening. Listeners got the opportunity to have each other's thoughts and beliefs with each other and apply new strategies in their own learning or the pre-listening and post-listening activities. Listeners are motivated to think about the process of listening by dealing with this process. In fact, they are learning to learn to listen and consequently, their Metacognitive awareness about how to learn listening will be enhanced.

The third activity is using the checklist of listening strategies when they have to listen and should use a checklist before and after listening and put tick according to the type strategies and listeners are encouraged to assess the appropriateness of their strategy use; listeners are obliged to make plans to improve their performance for the next time. This method is also good for introverted listeners who are unwilling to speak out in discussions (Yang, 2009).

\section{Conclusion}

To conclude, it should be noted that the traditional idea of only exposing EFL students to listening texts in listening classes should be challenged by an approach in which strategies can effectively and successfully be embedded to the listening course by means of strategy training program. Listening is an important and implicit 
process which most of the life activities depend on it. It is hoped that this study will cause more research exploring the effect of different strategy training models on students' performance in different basic skills. Studies proving the effectiveness of strategy training are likely to convince English teachers, teacher trainers, course book writers, and curriculum and syllabus designers to be more aware of the benefits of strategy training and include these strategies in their lessons, course books, and curricula. Due to the results of this study, the concluding remarked that Metacognitive awareness has a positive relationship with L2 listening proficiency. Although correlations do not show causation, the association regression analysis model indicated that for each one-unit increase in Metacognition, listening will increase an estimated 7.3 units, i.e., higher Metacognitive awareness is linked with higher L2 listening proficiency. Metacognitive awareness helps students to find opportunities in order to increase their listening performance.

\section{References}

Akbari, R. (2003). The relationship between the use of language learning strategies by Iranian learners of English, their foreign language proficiency, and the learners' IQ scores. IJAL, 6, 1-20.

Baleghizadeh, S., \& Rahimi, A. H. (2011). The relationship among listening performance, metacognitive strategy use and motivation from a self-determination theory perspective. Theory and Practice in Language Studies, 1(1), 61-67.

Bidabadi, F. S., \& Yamat, H. (2010). The relationship between listening strategies employed by Iranian EFL freshman university students and their learning style preferences. European Journal of Social Sciences, 16(3), 351-359.

Bidabadi, F., \& Yamat, H. (2011). The relationship between listening strategies used by Iranian EFL freshman university students and their listening proficiency levels. English Language Teaching, 4(1), 26-32.

Bueno, A., Madrid, D., \& McLaren, N. (Eds.). (2006). TEFL in secondary education. Granada: Editorial Universidad de Granada.

Choi, I., Land, S., \& Turgeon, A. (2005). Scaffolding peer-questioning strategies to facilitate metacognition during online small group discussion. Instructional Science, 33(5-6), 367-379.

Elkhafaifi, H. (2005). Listening comprehension and anxiety in the Arabic language classroom. The Modern Language Journal, 89(2), 206-220.

Fahim, M., \& Fakhri Alamdari, E. (2014). Maximizing learners' metacognitive awareness in listening through metacognitive instruction: An empirical study. International Journal of Research Studies in Education, 3(3), 79-91.

Flavell, J. H. (1979). Metacognition and cognitive monitoring: A new area of cognitive developmental inquiry. American Psychologist, 34, 906-911.

Goh, C. C. M. (2000). A cognitive perspective on language learners’ listening comprehension problems. System, $28,55-75$.

Goh, C. (2008). Metacognitive instruction for second language listening development: Theory, practice and research implications. RELC Journal, 39, 188-213.

Goh, C. C., \& Hu, G. (2014). Exploring the relationship between metacognitive awareness and listening performance with questionnaire data. Language Awareness, 23(3), 255-274.

Harputlu, L., \& Ceylan, E. (2014). The effects of motivation and metacognitive strategy use on EFL listening proficiency. Procedia-Social and Behavioral Sciences, 158, 124-131.

Hoare, C. (Ed.). (2011). The Oxford handbook of reciprocal adult development and learning. Oxford: Oxford University Press.

Lachini, K. (1997). The impact of language proficiency on language communication and learning strategies (Unpublished doctoral dissertation, Islamic Azad University, Tehran, Iran).

Lindsay, C., \& Knight, P. (2006). Learning and teaching English. Oxford: OUP.

Liu, S., \& Hsueh, J. (2008). Listening comprehension strategies and learning styles in foreign language education. Paper presented at the British Educational Research Association Annual Conference, Heriot-Watt University, Edinburgh.

Mills, N., Pajares, F., \& Herron, C. (2006). A reevaluation of the role of anxiety: Self-efficacy, anxiety, and their relation to reading and listening proficiency. Foreign Language Annals, 39, 276-295.

Nichols, R. G. (2006). The struggle to be human. International Journal of Listening, 20(1), 4-12.

Pishghadam, R. (2009). The relationship between the use of learning strategies with gender for learning English and the preferred learning strategies for learning English by Iranian students. Journal of the Literature and Humanities Faculty of Tabriz University, 208, 24-50. 
Rahimi, M., \& Abedi, S. (2014). The relationship between listening self-efficacy and metacognitive awareness of listening strategies. Procedia-Social and Behavioral Sciences, 98, 1454-1460.

Rahimi, M., \& Katal, M. (2012). Metacognitive strategies awareness and success in learning English as a foreign language: An overview. Procedia-Social and Behavioral Sciences, 31, 73-81.

Rahimi, M., \& Katal, M. (2013). The impact of metacognitive instruction on EFL learners’ listening comprehension and oral language proficiency. Journal of Teaching Language Skills, 32(2), 69-90.

Rahimi, M., \& Nabilou, Z. (2010). Iranian EFL teachers' effectiveness of instructional behavior in public and private high schools. Asia Pacific Education Review, 12, 67-78.

Ratebi, Z., \& Amirian, Z. (2013). The use of metacognitive strategies in listening comprehension by Iranian university students majoring in English: A comparison between high and low proficient listeners. Journal of Studies in Education, 3(1), 140-154.

Shirani Bidabadi, F., \& Yamat, H. (2010). The relationship between listening strategies used by Iranian EFL freshman university students and their listening proficiency levels. English Language Teaching, 4, 26-32.

Tafaroji Yeganeh, M. (2013). Metacognitive listening strategies awareness in monolingual versus bilingual EFL learners. Procedia-Social and Behavioral Sciences, 70, 1787-1793.

Tajedin, Z. (2001). Language learning strategies: A strategy-based approach to L2 learning, strategic competence, and test validation (Unpublished doctoral dissertation, Allameh Tabatabaee University, Tehran, Iran). Retrieved from www.irandoc.ir

Vandergrift, L. (1997). The comprehension strategies of second language (French) listeners: A descriptive study. Foreign Language Annals, 30(3), 387-409.

Vandergrift, L. (2003). From prediction through reflection: Guiding students: Through the process of L2 listening. Canadian Modern Language Review, 59(3), 425-440.

Vandergrift, L., \& Goh, C. C. (2012). Teaching and learning second language listening: Metacognition in action. New York: Routledge.

Vandergrift, L., \& Tafaghodtari, M. (2010). Teaching L2 learners how to listen does make a difference: An empirical study. Language Learning, 60, 470-497.

Vandergrift, L., Goh, C., Mareschal, C., \& Tafaghodtari, M. H. (2006). The metacognitive awareness listening questionnaire (MALQ): Development and validation. Language Learning, 56, 431-462.

Yang, C. (2009). A study of metacognitive strategies employed by English listeners in an EFL setting. International Education Studies, 2(4), 134. 